\title{
Assessment of Microbiological Quality of Processed Fruit Juice
}

\author{
MAbul Basar and Sabita Rezwana Rahman \\ Department of Microbiology, University of Dhaka, Dhaka 1000, Bangladesh
}

[Received 22 November 2007; Accepted 08 December 2007]

\begin{abstract}
The present study was performed to evaluate the microbiological quality of industrially processed packed juices such as mango, orange and lemon of five different local companies. Aerobic plate count (APC) in juice samples was nil when measured before and after neutralization of $\mathrm{pH}$. However, after enrichment of couple of samples growth of bacteria was observed on nutrient agar and MacConkey agar media. Sample A showed $120 \mathrm{cfu} / \mathrm{ml}$ after $3 \mathrm{~h}$ on nutrient agar and $20 \mathrm{cfu} / \mathrm{ml}$ after $5 \mathrm{~h}$ on MacConkey agar medium. These findings indicate that manufacturers might use high amount of preservatives that had bacteriostatic effect on microbes. It can be suggested that processed juices should be prepared under hygienic condition without use of high amount of preservatives that might cause health hazard.
\end{abstract}

Keywords: Fruit juice, Bacterial count, Preservatives, Enrichment

Fruit juices are very nutritive, invigorating and non-alcoholic beverage, which is very well liked throughout the world. Juice may be squeezed directly from fruits or may be extracted by water. These juices can be used in their natural concentrations or in processed form. They are very scrumptious and palatable and they have most of the minerals like calcium, magnesium, phosphorus, and sodium and vitamins specially vitamin $\mathrm{C}^{1}$. However, these processed juices contain mainly water, sugar, preservatives, colour, fruits pulps and other additives as ingredients and must maintain sanitary standard ${ }^{2}$. The most commonly used preservatives are benzoic acid, sorbic acid, or sulphur dioxide ${ }^{3}$. Natural colours such as anthocynins and betanin are used ${ }^{4}$. Acid is an essential universal constitution of soft drinks $^{3}$. The most commonly used acid is citric acid.

Most fruit juices contain sufficient nutrients that could support microbial growth. Several factors encourage, prevent, or limit the growth of microorganisms in juices; the most important are $a_{w}$, $\mathrm{pH}$, hygienic practice and storage temperature and concentration of preservative ${ }^{5-6}$. Storage of products at refrigerator temperature or bellow is not always best for the maintenance of desirable quality of some fruits ${ }^{7}$. Water used for juice preparation can be a major source of microbial contaminants such as total coliforms, faecal coliforms, faecal streptococci, etc ${ }^{8}$. Environmental formites may also make the fruits unsafe and these may have a role in spreading of Salmonella, Shigella, Vibrio, Escherichia coli, and other diseases causing as well as fruits spoilage types ${ }^{9}$. Spoilage yeasts, such as Saccharomyces cerevisiae, Candida lipolytica and Zygosaccharomyces spp. can tolerate acidic environments ${ }^{10}$. It should also be noted that changes in $\mathrm{pH}$ could transform a food into one, which can support growth of pathogens ${ }^{10}$.
The quality of soft drinks is strictly maintained in developed countries under some law and regulation but in many developing and under developed countries the manufacturer is not concern about the microbiological safety and hygiene of soft drinks because of negligence of law. Thus the transmission of some human diseases through juice and other drinks are considered a serious problem in recent years ${ }^{11}$.

The market for these products continues to show a remarkable potential for growth. The variety of products and packaging types continues to expand. In recent years these juices have been included significantly in diet of every person irrespective to age. So maintaining the quality of processed fruit juices is important issue now. In order to develop awareness among the people about fruit juices in transmitting diseases this study was attempted to measure microbiological quality of industrially processed fruit juices.

Five types of mango juices, three types of orange juices and two types of lemon juices were collected from different prevailed manufacturer in the Dhaka City for bacteriological analyses. At least 7 samples of each category were analyzed to overcome the sampling biasness. These samples were designated as A (mango), B (mango), C (mango), D (mango), E (mango), F (orange), $\mathrm{G}$ (orange), H (orange), I (lemon), and J (lemon).

Total heterotrophic bacterial and yeast counts were taken to determine the overall contamination by mesophilic bacteria. Total coliforms and faecal coliforms counts were done for assessing the faecal pollution, while staphylococcal count was chosen to assess the hygienic quality of plant personnel ${ }^{12}$. For heterotrophic bacteria, total coliforms, faecal coliforms, staphylococcal and

*Corresponding author:

Dr. Sabita Rezwana Rahman, Associate Professor, Department of Microbiology, University of Dhaka, Dhaka 1000, Bangladesh

Tel (Office): (02) 9661920-73, Ext 7746; Tel (Home): (02) 9351014; Fax: +880 (02) 8615583; E-mail: sabita_rahman@hotmail.com 
yeast counts, nutrient agar, MacConkey agar, mFC, mannitol salt agar and MYGP media were used respectively. Plating was performed by pour plate and spread plate methods using $1 \mathrm{ml}$ and $0.1 \mathrm{ml}$ sample. After inoculation the plates were incubated at $37^{\circ} \mathrm{C}$ for 24-48 h, except the mFC and MYGP plates that were incubated at $44.5^{\circ} \mathrm{C}$ and $28^{\circ} \mathrm{C}$ respectively.

In order to avoid acidity of the processed juice, $5 \mathrm{ml}$ original sample was neutralized by adding adequate amount of $0.1 \mathrm{~N} \mathrm{NaOH}$ and then the neutralized sample $(0.1 \mathrm{ml})$ was spread onto the surface of different media. To overcome the bacteriostatic activity of any added preservatives, the juice samples were first filtered through filter paper. Then the filter paper was placed on nutrient agar media, MacConkey and mFC medium and incubated overnight. Enrichment of sample was done by diluting $1 \mathrm{ml}$ original sample in $9 \mathrm{ml}$ nutrient broth medium and incubated at $37^{\circ} \mathrm{C}$ for 3-7 h. After time intervals (3, 5 and $8 \mathrm{~h}$ ), $0.1 \mathrm{ml}$ enriched sample was poured in nutrient agar medium and MacConkey medium and incubated at $37^{\circ} \mathrm{C}$ for $48 \mathrm{~h}$.

Industrially processed fruit juices were investigated for some physicochemical tests. Most of the drinks were light yellow to yellow in colour, sweet to taste and mainly good fruit flavour. The $\mathrm{pH}$ of the sample varied from 2.34 to 4.5 (Table 1). The total microbial counts including total coliform, faecal coliform, yeast and staphylococcal counts of different types of fruit juices were nil. This result is in contrast to the previous work that showed growth of bacteria including coliforms different juices ${ }^{13}$. The possible reasons for the present findings may be of many-fold. Firstly, the acidic pH (2.34 to 4.50) of juices might inhibit the growth of the bacteria present, and secondly, the juices might contain different types of preservatives. In order to prove these assumptions juice samples were neutralized and platted on various media, but the count was still nil in every cases. It is well known that the manufacturers commonly use sulphur dioxide $\left(\mathrm{SO}_{2}\right)$ and benzoate as preservatives in processed fruit juices ${ }^{14}$. Sulphur dioxide and benzoate can significantly damage the vegetative cells.

Table 1. The average $p H$ values of different processed fruit juices collected from grocery shops

\begin{tabular}{lc}
\hline Sample designation & $\mathrm{pH}$ value \\
\hline A (Mango juice) & 4.00 \\
B (Mango juice) & 3.88 \\
C (Mango juice) & 3.85 \\
D (Mango juice) & 4.10 \\
E (Mango juice) & 4.50 \\
F (Orange juice) & 3.21 \\
G (Orange juice) & 3.34 \\
H(Orange juice) & 3.50 \\
I (Lemon juice) & 2.34 \\
I (Lemon juice) & 2.40 \\
\hline
\end{tabular}

In this study two experiments were conducted to overcome the effects of chemical preservatives on microbes. Initially, the sample
(10 fold diluted) was allowed to pass through filter paper. The sticky thick juice could not pass through the filter even applying positive pressure. Total count from the filter was not possible. Therefore, enrichment strategy was undertaken involving dilution (10-fold) of the original juice in nutrient broth before culturing on different media. Using the enrichment culture, it was found that sampleA(mango juice) yielded 120, 220, $360 \mathrm{cfu} / \mathrm{ml}$ after incubation period of 3, 5 and 8 h respectively on nutrient agar medium. The same sample also gave 20-40 cfu/ml after incubation for 5-8 h on MacConkey agar medium (Table 2). Similarly, sample B (mango juice) also exhibited 160 and $400 \mathrm{cfu} / \mathrm{ml}$ after 5 and $8 \mathrm{~h}$ respectively on nutrient agar medium, and 20 and $30 \mathrm{cfu} / \mathrm{ml}$ after 5 and $8 \mathrm{~h}$ on MacConkey agar medium respectively. The mFC medium did not show any growth for the both sample. The colonies grown on MacConkey agar medium were identified by using biochemical tests as E. coli. The recommended microbiological standards for any fruit juice according Gulf standard ${ }^{15}$ is shown in Table 3.

Table 2. Bacterial counts of sample A and sample B on various media after enrichment

\begin{tabular}{lccc}
\hline Culture medium & \multicolumn{3}{c}{$\begin{array}{c}\text { Bacterial count (cfu/ml) in sample A / } \\
\text { sample B after enrichment for }\end{array}$} \\
\cline { 2 - 4 } & $3 \mathrm{~h}$ & $5 \mathrm{~h}$ & $8 \mathrm{~h}$ \\
\hline Nutrient agar & $120 / 0$ & $220 / 160$ & 360 / 400 \\
MacConkey agar & $0 / 0$ & $20 / 20$ & 40 / 30 \\
mFC agar & $0 / 0$ & 0 / 0 & 0 / 0 \\
\hline
\end{tabular}

Table 3. Gulf standard for microbiological criteria for foodstuffs

\begin{tabular}{lcc}
\hline $\begin{array}{l}\text { Count } \\
(\mathrm{cfu} / \mathrm{ml})\end{array}$ & $\begin{array}{c}\text { Maximum count } \\
\text { anticipated }\end{array}$ & $\begin{array}{c}\text { Maximum count } \\
\text { permitted }\end{array}$ \\
\hline Total count & $5.0 \times 10^{3}$ & $1.0 \times 10^{4}$ \\
Coliforms & 10 & 100 \\
Yeasts & 100 & $1.0 \times 10^{3}$ \\
\hline
\end{tabular}

The result of this study is alarming concerning the public health especially the children because the juice not only contains harmful microorganisms but also contains high amount of preservatives. It was proven that some manufacturers use up to 40 to $50 \mathrm{ppm}$ sulphur dioxide $\left(\mathrm{SO}_{2}\right)$ and/or benzoate in the juice, whereas the maximum approved level to human consumption is $10 \mathrm{ppm}^{16}$.

In Bangladesh unfortunately it is very difficult to monitor how the consumer can be affected by taking fruit juices. It is, therefore, better to monitor the proper management of the raw material and the production plant to prevent or minimize microbial contamination of juices ${ }^{9}$. The results have shown only E. coli in the fruit juices, which clearly indicates poor plant management and personnel hygiene. It also scrutinizes the lacking of proper quality control system for the preparation of fruit juices in industry. This contamination could also be occurred due to lacking of right storage condition and bad packaging.

Fruit juices have high nutritional value but often it cause health hazard to the individual. Most of the juice related outbreak occurs 
by the Salmonella spp., such as, S. typhymurium, S. enterica, S. muenchen etc. Enterotoxigenic Escherichia coli causes severe outbreak in $1980^{16}$. The low total viable count would not necessarily mean safe juice. Juice has to be free from unwanted preservatives. A preservative like sulphur dioxide $\left(\mathrm{SO}_{2}\right)$ is very detrimental to respiratory system of individuals ${ }^{17}$.

The government authorized institute (like BSTI) should take intensive investigation to control the microbial and chemical quality of the juices as well as the public awareness about the adulterated fruit juices should be increased.

\section{References}

1. FDA. 1999. Fruit morphology and composition. Center for Food Safety and Applied Nutrition United States Food and Drug Administration. Available at: http://vm.cfsan.fda.gov/ comm/ juicback.html. Accessed 06 August 2007.

2. Levine M.1961. Facts and fancies of bacterial indices in standards for water and foods. Food Technol. 15(2): 29-34.

3. Atlas RM. 1984. Microbiology, Fundamental and Applications, pp 682-683. Macmillan Publishing Company, New York.

4. Davies WP \& Houghton HW. 1987. Quality Control in Food Industry, $2^{\text {nd }}$ edn, Vol 4. Academic Press, London.

5. Troller JA. 1983. Sanitation in Food Processing. Academic Press, Inc, New York.

6. Jay JM. 1987. Modern Food Microbiology, $3^{\text {rd }}$ edn, p 641. CBS Publishers \& Distributors, New Delhi.

7. Matchis JF \& Liston J. 1968. Low temperature growth of Salmonella. J Food Sci. 35: 64145
8. Gill CO, McGinnis JC \& Badoni M. 1996. Use of total coliform or Escherichia coli counts to assess hygienic characteristics. Int J Food Microbiol. 31(1-3): 181-196.

9. Doyle MP, Beuchat LR \& Montville TJ. 2001. Food Microbiology. American Society for Microbiology, ASM Press, Washington DC.

10. ICMSF. 1980. Microbial Ecology of Foods. 1. Factors Affecting Life and Death of Microorganisms, p 311. International Commission on Microbiological Specification for Foods (ICMSF). Academic Press, Orlando.

11. Geldreich EE \& Bordner RH. 1971. Faecal contamination of fruits and vegetables during cultivation and processing for market: A review. J Milk Food Technol. 34: 184-192.

12. Kloos WE and Bannerman TL. 1999. Staphylococcus and Micrococcus. In Manual of Clinical Microbiology (Murry PR, Baron EJ, Pfaller MA, Tenover FC \& Yolken RH eds), $7^{\text {th }}$ edn, pp. 264-282. ASM Press, Washington DC.

13. Nahar Z, Rahman SR \& Gomes DJ. 2006. Microbiological quality assessment of processed fruit drinks. Bangladesh J Microbiol. 23(1): 71-74.

14. BSTI. 2005. Bangladesh Standard Specification for Drinking Water. BDS 11150. Bangladesh Standard and Testing Institute (BSTI). Dhaka.

15. Gulf Standards. 2000. Microbiological Criteria for Foodstuffs, Part l. GCC, Riyadh.

16. Parish ME. 1997. Public health and non-pasteurized fruit juice. Critic Rev Microbiol. 23(2): 169-119.

17. Fowlie J, Grasso P \& Benford DJ. 2006. The short-term effects of carcinogens and sulphur dioxide on the nuclear size of rat nasal epithelial cells. J Appl Toxicol. 10(1): 29-38. 